\title{
A modern description of Crambionella stuhlmanni (Scyphozoa: Rhizostomeae) from St Lucia Estuary, South Africa
}

\author{
SIMONE NEETHLING ${ }^{1}$, ALAN CHANNING ${ }^{1}$, LISA-ANN GERSHWIN ${ }^{2}$ AND MARK J. GIBBONS ${ }^{1}$ \\ ${ }^{1}$ Department of Biodiversity and Conservation Biology, University of the Western Cape, Private Bag X17, Bellville 7535, \\ South Africa, ${ }^{2}$ Queen Victoria Museum and Art Gallery, Launceston, Tasmania 7250, Australia
}

\begin{abstract}
A new record of Crambionella stuhlmanni is reported from the east coast of South Africa. The material is described using quantitative morphological data, and mitochondrial (CO1) and nuclear (ITS-1) sequence data. The species can be diagnosed by a combination of morphological features including the presence of conical projections on velar lappets, the absence of orbicular appendages among mouthlets and the short length of the terminal club on the oral arm. Mitochondrial sequence data unambiguously delineate C. stuhlmanni as a separate species from C. orsini, and phylogenetic analyses support its placement within the monophyletic genus, Crambionella.
\end{abstract}

Keywords: Rhizostomeae, taxonomy, systematics, morphological analyses, molecular analyses

Submitted 21 April 2010; accepted 3 August 2010

\section{INTRDDUCTION}

South Africa is bathed by the warm Agulhas Current on the east coast and by the cool Benguela Current along the west coast: it is an environment that is characterized by the presence of a number of clear biogeographical provinces characterized by distinct communities of marine organisms (e.g. Emanuel et al., 1992; Gibbons et al., 2010a). As a consequence, it supports a remarkably high diversity of marine life (Gibbons et al., 1999). While the diversity of organisms associated with the benthos is substantially greater than that in the pelagos, the region typically supports a greater proportion of global species in the latter than former environments (Gibbons et al., 2010a). But, whilst $57 \%$ of the world's planktic urochordates or euphausiids have been reported from the region only $\sim 7 \%$ of the world's scyphozoans have been formally logged (Gibbons et al., 1999). Given both their conspicuousness (most Scyphozoa are of a relatively large size and many bloom on a seasonal basis) and the fact that the region has been explored by many of the Great Expeditions, this is somewhat surprising.

Globally, however, our understanding of scyphozoan diversity is relatively poor and a total of only $\sim_{200}$ species have been described to date (Mianzan \& Cornelius, 1999). This number is probably artificially low, given their meroplanktic nature (Gibbons et al., 2010b), and likely reflects the conserved nature of medusoid morphology (Hamner \& Dawson, 2009). Many of the original descriptions of scyphozoans are archaic, being based on a few subjective and qualitative diagnostic characters (Bolton \& Graham, 2004 Dawson, 2005a), so the foundation on which our knowledge

Corresponding author:

M.J. Gibbons

Email: mgibbons@uwc.ac.za has been based is weak at best. To add to this confusion, some species are now known to display considerable phenotypic plasticity (Dawson et al., 2001; Dawson, 2005a), and crypsis is becoming more widely reported (Dawson \& Jacobs, 2001; Schroth et al., 2002; Holland et al., 2004; Dawson, 2004, 2005b). Although morphological descriptions are still essential when documenting diversity, there is a desperate need to revise them using more objective and quantitative features, supplemented where possible with molecular data (Dawson \& Jacobs, 2001; Schroth et al., 2002; Dawson, 2003, 2004, 2005b, c; Holland et al., 2004; McManus \& Katz, 2009). Here we describe a species of Crambionella (Scyphozoa: Rhizostomeae) from the St Lucia Estuary using just such an approach, in part to set a modern descriptive standard for the wider taxon and in part to allow identification of the present material.

The genus Crambionella is an inscapulate daktyliophore (Scyphozoa: Rhizostomae), with an intra-circular network of anastomosing canals that communicates with the ring canal (not stomach), occasionally with adjacent radial canals (Stiasny, 1922; Kramp, 1961). Lappets are separated by a deep furrow and are free of any anastomosing canals (Stiasny, 1922, 1937; Rao, 1931). This genus possesses three winged oral arms with terminal clubs, pyramidal in shape, lacking any whip-like filaments (Rao, 1931; Kramp, 1961). Three species are presently known, and all are confined to the Indian Ocean. Crambionella orsini (Vanhöffen, 1888) was first described from the Red Sea and is known to bloom seasonally in the north-west Indian Ocean (Billet et al., 2006; Daryanabard \& Dawson, 2008). Crambionella stuhlmanni (Chun, 1896) was originally described from the mouth of the Quilimane River, East Africa and C. annandalei Rao, 1931 was first identified from material collected off of the coast of Chennai (formerly Madras), India. The three species can be separated primarily on the basis of the presence of conical projections on velar lappets, accessory orbicular 
mouth appendages on the oral arms as well as the proportion of terminal club length to oral arm length, and their respectively isolated geographical ranges within the Indian Ocean (Vanhöffen, 1888; Chun, 1896; Mayer, 1910; Stiasny, 1922, 1937; Menon, 1930; Roa, 1931; Ranson, 1945; Nair, 1946; Kramp, 1956, 1961, 1970).

\section{MATERIALS AND METHODS}

Forty-eight specimens of Crambionella (Figure 1) were collected by dip-netting from the St Lucia Estuary $\left(28^{\circ} \mathrm{o}^{\prime} \mathrm{O}^{\prime \prime} \mathrm{S}\right.$ $32^{\circ} 30^{\prime} \mathrm{o}^{\prime \prime} \mathrm{E}$ ) during December 2005, and were preserved immediately in $5 \%$ ambient seawater-formalin. The St Lucia Estuary forms part of the iSimangaliso Wetland Park (UNESCO, 2008) which is a World Heritage Site situated on the north-east coast of South Africa. This estuarine system is the largest in Africa occupying an area of approximately $325 \mathrm{~km}^{2}$ (Fielding et al., 1991), and is made up of three main lakes with an average depth of less than $1 \mathrm{~m}$ (Anonymous, 2008) that connect to the sea through a $22 \mathrm{~km}$ long channel (100-200 m wide) (Cyrus et al., 2010). The wetland park lies between tropical and sub-tropical climatic zones, and is typified by warm moist summers and mild dry winters; mean annual temperatures routinely surpass $21^{\circ} \mathrm{C}$ (Anonymous, 2008). It is prone to seasonal flooding in summer and periods of drought leading to temporary mouth closures and associated fluctuations in salinity during winter (Fielding et al., 1991; Cyrus et al., 2010; Jerling et al., 2010). By comparison with many estuarine systems in South Africa, that of St Lucia is considered to be fairly well understood (Pillay \& Perissinotto, 2008).

\section{Morphological data collection}

After 22 months in preservation, thirty-six morphological features were measured under magnification from 44 specimens (Table 1; Figure 2) using Vernier callipers. After all bell measures were taken, the oral arms were removed and the radial canal system was injected with coloured latex to highlight its arrangement. Five un-dissected specimens were

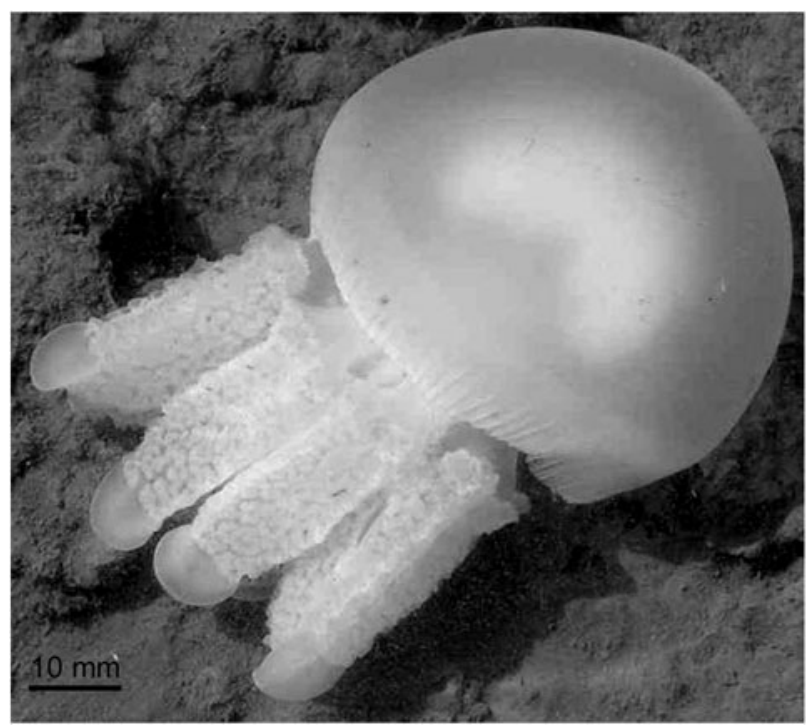

Fig. 1. A photograph of a live specimen from St Lucia Estuary (Ricky Taylor, Ezemvelo KZN Wildlife). deposited at the Iziko South African Museum, Cape Town: accession number SAMCT H5110.

Comparisons were made between the measured variables of the St Lucia material and those of five good specimens of Crambionella orsini in the collections at the Natural History Museum, London (specimen numbers detailed below). Owing to the fact that this material had to be studied in a nondestructive way, not all measures could be repeated and discrepancies are indicated in Table 1.

\section{Morphological data analyses}

In order to determine the effect of individual size (external bell diameter, $\mathrm{S}_{1}$ ) on measured variables; Pearson's R correlations or Spearman's rank correlations (for those variables that failed tests of normality) were computed following $\log _{10}$ transformation of data (Zar, 1999). Test results were considered significant, following Bonferonni corrections for Type I errors (Quinn \& Keough, 2002). Some morphological measures were expressed as proportions following Chun (1896), Mayer (1910), Menon (1930, 1936), Rao, (1931), Stiasny (1937) and Kramp (1961). These included: oral disc diameter (S 13) to external umbrella diameter $\left(\mathrm{S}_{1}\right)$; length of the distal oral arm portion $\left(\mathrm{S}_{7}\right)$ to length of the proximal oral arm portion (S6); length of terminal club $\left(\mathrm{S}_{11}\right)$ to total oral arm length (S6 and $\left.\mathrm{S}_{7}\right)$; ostia width $\left(\mathrm{S}_{15}\right)$ to inter-ostia width $\left(\mathrm{S}_{15}\right)$ and umbrella height $\left(\mathrm{S}_{3}\right)$ to external umbrella diameter $\left(\mathrm{S}_{1}\right)$.

Given that many of the variables did change with individual size (see below), which complicates straightforward field comparisons, raw morphometric data were standardized by dividing them by external bell diameter ( $\mathrm{S}_{1}$; except the aforementioned proportions), and $\log _{10}$ ratios were correlated with $\log _{10}$ size in an effort to eliminate size dependency. Comparisons between the standardized measurements of the St Lucia material and those of C. orsini were computed as above.

In order to test for morphological differences between individual logged ratios and between untransformed meristic measures, of the Crambionella specimens from the St Lucia Estuary and those of $C$. orsini two-tailed $t$-tests were computed, and the results inspected following Bonferroni corrections. All univariate statistical analyses were executed using STATISTICA v. 7.

In order to visualize and test for multivariate differences between the St Lucia material and that of $C$. orsini from the Natural History Museum, London, we have used a variety of the non-parametric routines within the PRIMER 6 \& PERMANOVA+ software (Clarke \& Gorley, 2006; Anderson et al., 2008). A similarity matrix based on Euclidean distance was first constructed between the multivariate states (untransformed standardized measures) of all specimens. In order to maximize the number of individuals used, gaps were filled either by mean substitution (if there was no significant relationship of the considered feature with size) or from regression equations: invariant meristic features were excluded. Non-metric multi-dimensional scaling (NMDS) was used to visualize relationships in multivariate space (Clarke, 1993) and a one-way analysis of similarities (ANOSIM) test was used (a priori) to test the null hypothesis of no morphological dissimilarity between species (Clarke \& Warwick, 2001). This latter routine computes an $R$ statistic that measures the average distance between every specimen within a group and contrasts it to the average distance between every specimen from the other group. ANOSIM 
Table 1. Morphological features ( $\mathrm{S}$ ) of Crambionella specimens used in data analyses. Specimens were collected from St Lucia Estuary, on the northeast coast of South Africa, during December 2005 and preserved in 5\% formalin in ambient seawater. Figure references are given where applicable. As C. orsini material examined at the Natural History Museum, London, had to be studied in a non-destructive way some measurements had to be excluded; measurements taken on C. orsini specimens are indicated $\left(^{*}\right)$.

\begin{tabular}{|c|c|c|c|c|c|}
\hline $\begin{array}{l}\text { Morphological } \\
\text { feature number }\end{array}$ & $\begin{array}{l}\text { Figure reference } \\
\text { number }\end{array}$ & $\begin{array}{l}\text { Morphological feature } \\
\text { description (measured in } \mathbf{m m} \text { ) }\end{array}$ & $\begin{array}{l}\text { Morphological } \\
\text { feature number }\end{array}$ & $\begin{array}{l}\text { Figure reference } \\
\text { number }\end{array}$ & $\begin{array}{l}\text { Morphological feature } \\
\text { description (measured in } \mathrm{mm} \text { ) }\end{array}$ \\
\hline $\mathrm{S}_{1}{ }^{*}$ & - & $\begin{array}{l}\text { External umbrella diameter to } \\
\text { tip of lappets }\end{array}$ & $\mathrm{S} 19^{*}$ & - & Width of oral pillars \\
\hline $\mathrm{S}_{2} *$ & - & $\begin{array}{l}\text { External umbrella diameter to } \\
\text { base of lappets }\end{array}$ & $\mathrm{S} 20$ & - & $\begin{array}{l}\text { Internal umbrella diameter to tip } \\
\text { of lappets }\end{array}$ \\
\hline $\mathrm{S}_{3}$ & Figure 2 & Umbrella height & $S_{21}$ & - & $\begin{array}{l}\text { Internal umbrella diameter to } \\
\text { base of lappets }\end{array}$ \\
\hline $\mathrm{S}_{4}$ & Figure 2 & Umbrella thickness & $S_{22}$ & Figure 2 & Ring canal diameter \\
\hline $\mathrm{S}_{5}{ }^{*}$ & - & Width of oral arm base & $\mathrm{S} 23$ & Figure 2 & $\begin{array}{l}\text { Gonadal diameter along } \\
\text { perradial axis }\end{array}$ \\
\hline S6* & Figure 2 & $\begin{array}{l}\text { Length of the proximal (naked) } \\
\text { portion of the oral arm }\end{array}$ & $\mathrm{S} 24$ & Figure 2 & $\begin{array}{l}\text { Gonadal diameter along adradial } \\
\text { axis }\end{array}$ \\
\hline $\mathrm{S}_{7}^{*}$ & Figure 2 & $\begin{array}{l}\text { Length of the distal portion } \\
\text { (winged and terminal club) of } \\
\text { the oral arm }\end{array}$ & $\mathrm{S} 25^{*}$ & Figure 2 & $\begin{array}{l}\text { Number of velar lappets in } \\
\text { octant }\end{array}$ \\
\hline S8* & Figure 2 & $\begin{array}{l}\text { Depth of oral arm (including } \\
\text { naked and ventral winged } \\
\text { portion) }\end{array}$ & S 26 & - & $\begin{array}{l}\text { Number of conical projections } \\
\text { on velar lappets }\end{array}$ \\
\hline $\mathrm{S}^{*}$ & - & $\begin{array}{l}\text { Depth of naked portion of oral } \\
\text { arm }\end{array}$ & $\mathrm{S} 27^{*}$ & - & Number of rhopalia \\
\hline $\mathrm{S}_{10} 0^{*}$ & Figure 2 & $\begin{array}{l}\text { Depth of winged portion of oral } \\
\text { arm }\end{array}$ & $\mathrm{S} 28$ & Figure 2 & Number of rhopalial canals \\
\hline $\mathrm{S}_{11}{ }^{*}$ & Figure 2 & $\begin{array}{l}\text { Length of terminal clubs of oral } \\
\text { arms }\end{array}$ & S 29 & - & $\begin{array}{l}\text { Point of termination for } \\
\text { rhopalial canals }\end{array}$ \\
\hline $\mathrm{S}_{12}{ }^{*}$ & - & $\begin{array}{l}\text { Width of terminal clubs of oral } \\
\text { arms }\end{array}$ & $\mathrm{S}_{30}$ & Figure 2 & $\begin{array}{l}\text { Number of inter-rhopalial } \\
\text { canals }\end{array}$ \\
\hline $\mathrm{S}_{13}{ }^{*}$ & Figure 2 & Oral disc diameter & $\mathrm{S}_{31}$ & - & $\begin{array}{l}\text { Point of termination for } \\
\text { inter-rhopalial canals }\end{array}$ \\
\hline $\mathrm{S}_{14}{ }^{*}$ & Figure 2 & Inter-ostia width & $\mathrm{S}_{32}$ & Figure 2 & $\begin{array}{l}\text { Number of anastomoses } \\
\text { connecting with the ring } \\
\text { canal }\end{array}$ \\
\hline $\mathrm{S}_{15^{*}}$ & Figure 2 & Width of ostia & $\mathrm{S}_{33}$ & Figure 2 & $\begin{array}{l}\text { Number of anastomoses } \\
\text { connecting with adjacent } \\
\text { inter- and rhopalial canals }\end{array}$ \\
\hline $\mathrm{S} 16^{*}$ & - & Length of ostia & S 34 & Figure 2 & $\begin{array}{l}\text { Number of anastomoses } \\
\text { connections within the } \\
\text { network }\end{array}$ \\
\hline $\mathrm{S}_{17}$ & Figure 2 & Depth of oral pillars & $\mathrm{S}_{35}$ & Figure 2 & $\begin{array}{l}\text { Number of primary folds in each } \\
\text { section of gonads }\end{array}$ \\
\hline $\mathrm{S}_{1} 8^{*}$ & - & Length of oral pillars & $\mathrm{S}_{36}$ & Figure 2 & Number of annular muscles \\
\hline
\end{tabular}

then performs a series (999) of permutation tests, wherein variables from each group (species) are randomly distributed between groups, and the $R$ statistic is recalculated. If the original $R$ statistic is more extreme than $95 \%$ of the permutations the null hypothesis is rejected at a level of $P<0.05$.

In order to determine which of the variables contributed the most to dissimilarity between species, we used the similarity percentages (SIMPER) routine in PRIMER 6 (Clarke, 1993). SIMPER determines the average dissimilarity between all pairs of inter-group specimens (Clarke \& Warwick, 2001). These averages are then disaggregated into the percentage that each variable contributes to overall dissimilarity amongst groups (Clarke \& Warwick, 2001).

Finally, we used the canonical analysis of principal coordinates (CAP) routine in PRIMER 6 \& PERMANOVA +, which is analogous to a discriminant functions analysis, in order to determine what percentage of St Lucia and C. orsini specimens were allocated to respective species groups. The CAP routine seeks a set of axes that best discriminates amongst a priori groups in multivariate space (Anderson et al., 2008). Anderson et al. (2008) describe the processes executed within this routine. Numerous matrices are generated to produce a set of canonical axes. Conventionally in a canonical discriminant analysis a subset of principal co-ordinate (PCO) axes are chosen manually, based on the number of variables in the original data matrix. However, in the present study, as the number of standardized morphometric features approached the number of specimens, Anderson et al. (2008) suggest 'leave-one-out' diagnostics to determine the subset of PCO axes. The PCO axes determined are all orthonormal and are therefore independent of each other. Running parallel to this process is a matrix based on codes for groups identified by a factor associated with the Euclidean distance matrix, also orthonormalized. An additional matrix is then generated by relating the subset of PCO axes to an orthonormalized data matrix, yielding canonical eigenvalues and their associated eigenvectors which can be used to produce a CAP plot. These CAP axes, which are linear combinations of a subset 

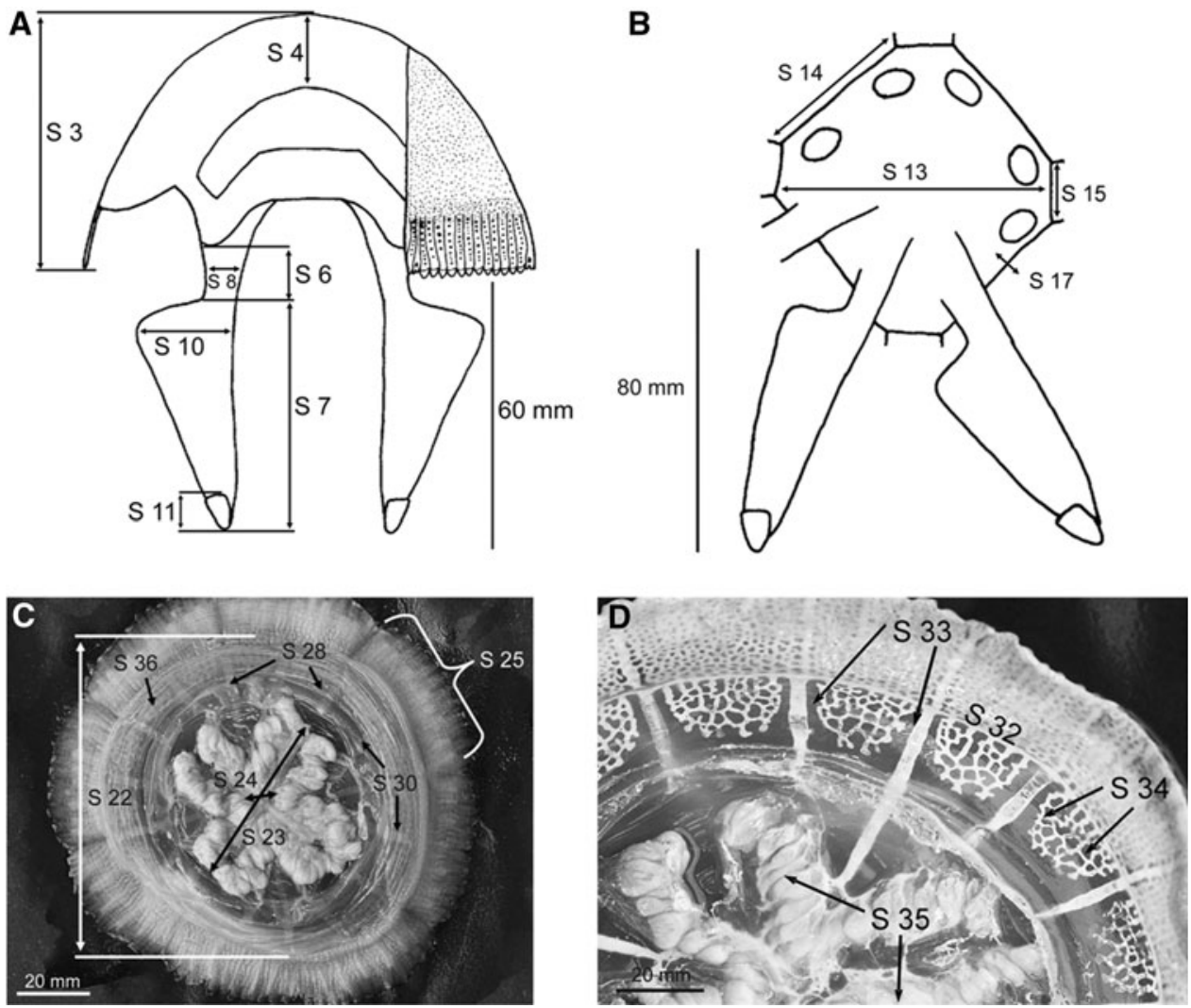

Fig. 2. Morphological features measured on Crambionella specimens collected from St Lucia Estuary, on the north-east coast of South Africa, during December 2005. (A) A schematic diagram of a longitudinal section along the perradial axis of a specimen (adapted from Dawson, 2005e); (B) a schematic diagram of the oral disc, from a subumbrella view (adapted from Dawson, 2005e). Only two of the eight oral arms are shown in A and B, and the key to all features (letters) measured should be sought from Table 1. Photographs showing the subumbrella view of a Crambionella medusa illustrating various morphological measurements (C) and the intra-circular and extra-circular anastomosing canal networks, after injecting coloured dye latex (D).

of orthonormal PCO axes, were used to determine if predefined groups were correctly classified. The CAP routine was also used to test the null hypothesis of no differences in the positions of centroids among groups in a multivariate space through a series of permutation tests (Anderson et al., 2008). This routine makes no assumptions about the underlying distribution of variables rendering it suitable for nonparametric analyses (Anderson et al., 2008).

\section{DNA analysis}

Three specimens of Crambionella were collected from the St Lucia Estuary at Charters Creek during September 2008, and immediately preserved in $99 \%$ ethanol. Material was stored at $-20{ }^{\circ} \mathrm{C}$ prior to analysis in the laboratory.

DNA was extracted from ethanol-preserved oral arm tissues using a phenol-chloroform based method. Samples were placed in separate Eppendorf tubes. Extraction buffer (SDS 0.5\%; 50 Mm Tris; 0.4 M EDTA; $\mathrm{pH}$ 8.0) in quantities of $0.5 \mathrm{ml}$ were pipetted over each sample. Tissue samples were then macerated. Proteinase $\mathrm{K}(20 \mathrm{mg} / \mathrm{ml})$ in quantities of $10 \mu \mathrm{l}$ was then added. Samples were vortexed and incubated at $55^{\circ} \mathrm{C}$ for a minimum of three hours until the majority of protein was digested. Samples were then mixed with $500 \mu l$ phenol:chloroform:isoamyl alcohol (24:24:1), finger vortexed, then centrifuged at low speed $(5000 \times \mathrm{g})$ for 10 minutes. Supernatants were removed and placed in new Eppendorf tubes, mixed with $500 \mu \mathrm{l}$ chloroform:isoamyl alcohol (24:1) and finger vortexed. Solutions were then centrifuged at low speed $(5000 \times \mathrm{g})$ for 10 minutes. Supernatants were removed and placed in new Eppendorf tubes. DNA was precipitated with $45 \mu \mathrm{N} \mathrm{Na}$ acetate and $650 \mu \mathrm{l}$ of ice cold ethanol and left to incubate at $-18^{\circ} \mathrm{C}$ overnight. Samples were then centrifuged at high speed $(13000 \times \mathrm{g})$ for 10 minutes and supernatants were discarded. Eppendorf tubes were inverted and left to air dry for a minimum of an hour. Each DNA sample was finally resuspended in $50 \mu \mathrm{l}$ TE buffer.

Cytochrome $c$ oxidase subunit I (COI) was amplified using primers LCOjf ( $5^{\prime}$-ggtcaacaaatcataaagatattggaac- $\left.3^{\prime}\right)$ and HCOcato ( $5^{\prime}$-ctccagcaggatcaaagaag- $3^{\prime}$ ) (Dawson, 2005d) or $\mathrm{HCO}_{2198}$ (5'-taaacttcagggtgaccaaaaaatca-3') (Folmer et al., 1994). Internal transcribed spacer one (ITS 1 ) was amplified using the primers jfITS $1-5 \mathrm{f} \quad\left(5^{\prime}\right.$-ggtttcgtaggtgaacctgcggaa ggatc- $\left.3^{\prime}\right)$ and jfITS $1-3$ r $\left(5^{\prime}\right.$-cgcacgagccgagtgatccaccttagaag- $\left.3^{\prime}\right)$ (Dawson \& Jacobs, 2001). Sequences were amplified through polymerase chain reaction (PCR) and PCR conditions were different for each fragment analysed. PCR conditions (adapted from Daryanabard \& Dawson, 2008) are summarized in Table 2. PCR products were purified and sequenced at the Central Analytical Facility, University of Stellenbosch. Electopherograms were checked visually, misreads corrected and poorly resolved terminal portions of sequences were discarded using Sequencher 4.9. Forward and reverse sequences were then aligned, using default settings, in Sequencher 4.9. Sequence identifications were verified by BLAST in GenBank.

Phylogenetic analyses were utilized to examine family level relationships using COI rhizostome sequences received from Professor M.N. Dawson, also available on GenBank. The 
Table 2. Polymerase chain reaction (PCR) conditions used to amplify cytochrome $c$ oxidase subunit I (COI) and internal transcribed spacer one (ITS1) from Crambionella specimens collected from St Lucia Estuary, on the northeast coast of South Africa, during December 2005 and preserved in absolute ethanol (adapted from Daryanabard \& Dawson, 2008).

\begin{tabular}{llll}
\hline $\begin{array}{l}\text { Number } \\
\text { of cycles }\end{array}$ & PCR steps & COI & ITS1 \\
\hline One & $\begin{array}{l}\text { Initial } \\
\text { denaturation } \\
\end{array}$ & 8 minutes at $94{ }^{\circ} \mathrm{C}$ & 8 minutes at $94{ }^{\circ} \mathrm{C}$ \\
& $\begin{array}{l}\text { Annealing } \\
\text { Extension }\end{array}$ & 2 minutes at $49{ }^{\circ} \mathrm{C}$ & 2 minutes at $51.5{ }^{\circ} \mathrm{C}$ \\
& Denaturation & 4 minutes at $72{ }^{\circ} \mathrm{C}$ & 2 minutes at $72{ }^{\circ} \mathrm{C}$ \\
One & Annealing & 2 minutes at $50^{\circ} \mathrm{C}$ & 2 minutes at $94{ }^{\circ} \mathrm{C}$ \\
& Extension & 2 minutes at $72{ }^{\circ} \mathrm{C}$ & 2 minutes at $72{ }^{\circ} \mathrm{C}$ \\
& Denaturation & 45 seconds at $94{ }^{\circ} \mathrm{C}$ & 45 seconds at $94{ }^{\circ} \mathrm{C}$ \\
33 & Annealing & 45 seconds at $51{ }^{\circ} \mathrm{C}$ & 45 at $53.5{ }^{\circ} \mathrm{C}$ \\
& Extension & 1 minute at $72{ }^{\circ} \mathrm{C}$ & 1 minute at $72{ }^{\circ} \mathrm{C}$ \\
& Final extension & 5 minutes at $72{ }^{\circ} \mathrm{C}$ & 5 a minutes $72{ }^{\circ} \mathrm{C}$ \\
One & Final hold & $4{ }^{\circ} \mathrm{C}$ & $4{ }^{\circ} \mathrm{C}$ \\
One & & & \\
\hline
\end{tabular}

following sequences were utilized: Cassiopea andromeda (samples from Bermuda, AY319463 and AY319465); C. frondosa (sampled from Panama, AY319469 and AY319470); C. ornata (sampled from Palau, AY31945); C. ornata (sampled from Berau, AY319472); Mastigias papua (sampled from Palau, EU363340 and AY902982); M. papua (sampled from Berau, AY903048 and AY903049); Phyllorhiza punctata (sampled from Australia, $\mathrm{EU}_{3} 63341$ and EU363342; Catostylus mosaicus (sampled from Australia, AY737184 and AY737216); Crambionella orsini (sampled from Iran,

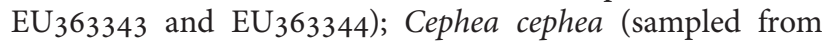
Palau, EU363345; C. cephea (sampled from Kwajalein,

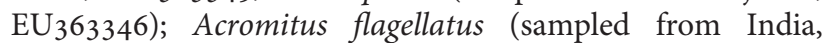
$\mathrm{EU}_{3} 63347$ and $\mathrm{EU}_{363348)}$ and Nemopilema nomurai (AB243416). Aurelia aurita (Ulmaridae) has been used as an outgroup, as the order Semaeostomeae are now recognized to form the subclass Discomedusae with Rhizostomeae (Collins, 2002; Dawson, 2004; Marques \& Collins, 2004; Collins et al., 2006). Sequence data for A. aurita (sampled from Korea) were downloaded from GenBank (EFo10537). Prior to further analyses, all sequence lengths were edited in Sequencher 4.9. A parsimony analysis was performed under direct optimization in the program POY 4.1.1 (Varón et al., 2009) which simultaneously optimizes nucleotide homology and tree costs, thereby reducing the set of assumptions throughout the analysis. Bootstrap analyses (1500 pseudoreplicates) were performed to assess support of branch nodes. Mean pairwise sequence differences, using uncorrected ' $P$ ', distances were calculated in PAUP* $10.4 \mathrm{~b}$.

\section{RESULTS}

\section{SYSTEMATICS}

Order RHIZOSTOMEAE Cuvier, 1799 Suborder DAKTYLIOPHORAE Stiasny, 1921 Superfamily INSCAPULATAE Stiasny, 1921 Family CATOSTYLIDAE Gegenbaur, 1857

Genus Crambionella Stiasny, 1921

Crambionella stuhlmanni (Chun, 1896)

(Figures 1-5; Tables 1-6)

\section{SYNONYMY}

Crambessa stuhlmanni Chun, 1896: 10, figure 1, pl. I, figure 1; Stiasny, 1922: 50, figure 3.

Catostylus stuhlmanni Mayer, 1910: 669; Crambionella stuhlmanni Stiasny, 1921: 129; Stiasny, 1937: 237; Ranson, 1945: 319; Kramp, 1961: 374

\section{COMPARATIVE MATERIAL EXAMINED}

Five preserved specimens of $C$. orsini were examined from the Natural History Museum, London, all collected on the 'Murray' expedition in 1933: 1950.3.25.343 (Station 76; 29 November 1933; $2 \mathrm{~m}$ tow net, $2800 \mathrm{~m}$ wire out); 1950.3.25.346 (Station 71; 26 November 1933; otter net, $106 \mathrm{~m}$ ); 1950.3.25.347 (Station 70; 25 November 1933; otter net, $199 \mathrm{~m}$ ); 1950.3.25.356 (Anchorage Muscat; 22 November 1933; Hand net, surface); 1950.3.25.357 (Station 75; 28 November 1933; otter net, $210 \mathrm{~m}$ ).

\section{DESCRIPTION}

Umbrella between 62 and $181 \mathrm{~mm}$ in diameter (Table 3), finely granular, hemispherical or dome-shaped; margin cleft into narrow velar lappets, separated by deep furrows. Eight oral
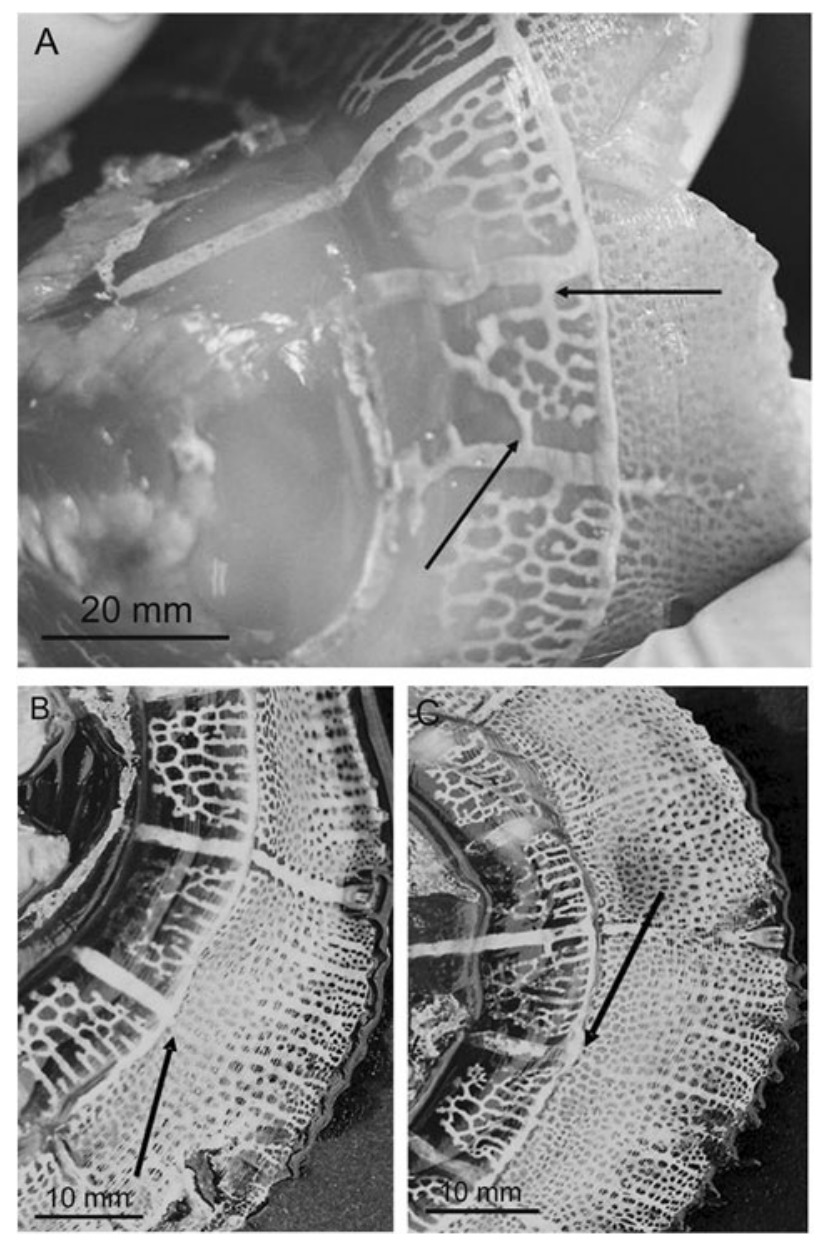

Fig. 3. Photographs showing the subumbrellar view of a Crambionella medusa collected in the St Lucia Estuary illustrating anastomosing canal network connections to both the rhopalial and inter-rhopalial canals, after injecting coloured dye latex (A) and inter-rhopalial canals that appear to extend beyond the ring canal $(\mathrm{B}, \mathrm{C})$. On closer inspection more than one canal originated from ring canal section and was thinner than canals that preceded the ring canal. Inter-rhopalial canals were therefore accepted to terminate at the ring canal. 
Table 3. A summary of all Crambionella specimen measures from St Lucia Estuary and C. osini specimens examined from the Natural History Museum, London. Highlighted variables (bold typeface) are logged variables that were significantly correlated, using either Pearson's $\mathrm{R}\left(P<0.0014\right.$, accepting Bonferonni correction) or Spearman's rank correlation $\left(P<0.02\right.$, accepting Bonferonni correction) test, with external bell diameter $\left(\mathrm{S}_{1}\right)$ in the case of the St Lucia specimens. Excluded measurements are $S_{1}, S_{2}, S_{29}$ and $S_{31}$ (indicated by ${ }^{\dagger}$ ). Max, maximum; min, minimum.

\begin{tabular}{|c|c|c|c|c|c|c|c|c|c|c|c|c|c|c|}
\hline \multirow[t]{2}{*}{ Morphological feature } & \multicolumn{7}{|c|}{ Crambionella (St Lucia) } & \multicolumn{7}{|c|}{ Crambionell orsini (NHM) } \\
\hline & Max & Min & Mean & SD & $\mathbf{N}$ & Median & Mode & $\operatorname{Max}$ & Min & Mean & SD & $\mathbf{N}$ & Median & Mode \\
\hline $\mathrm{S}_{1}^{\dagger}$ & 181 & 62 & 119.53 & 29.75 & 38 & 121 & 135 & 165 & 114 & 147.6 & 19.53 & 5 & 152 & 152 \\
\hline $\mathrm{S}_{2}^{\dagger}$ & 158 & 54 & 96.79 & 24.70 & 38 & 98 & 102 & 144 & 100 & 132.8 & 18.46 & 5 & 139 & 139 \\
\hline $\mathrm{S}_{3}$ & 46.5 & 24.9 & 36.33 & 10.51 & 4 & 36.95 & - & - & - & - & - & - & - & - \\
\hline$S_{4}$ & 29.4 & 4.7 & 13.90 & 6.17 & 44 & 11.8 & 11 & - & - & - & - & - & - & - \\
\hline $\mathrm{S}_{5}$ & 9.2 & 1 & 4.43 & 1.24 & 44 & 4.4 & 5 & 8 & 3.5 & 5.61 & 1.03 & 5 & 5.5 & 5 \\
\hline S6 & 19 & 1 & 9.35 & 3.13 & 44 & 10 & 11 & 14.5 & 5 & 9.27 & 2.78 & 5 & 8 & 8 \\
\hline$S_{7}$ & 45.4 & 1.6 & 24.83 & 8.16 & 44 & 26.75 & 30 & 52 & 26 & 40.04 & 6.85 & 5 & 41 & 41 \\
\hline S8 & 19 & 3 & 10.66 & 3.09 & 44 & 11 & 11 & 17 & 8 & 12.07 & 2.26 & 5 & 12 & 12 \\
\hline S9 & 10 & 1.5 & 5.67 & 1.72 & 44 & 6 & 6 & 8.5 & 3.5 & 5.91 & 1.41 & 5 & 6 & 6 \\
\hline S10 & 29 & 3 & 15.19 & 4.26 & 44 & 15.6 & 15 & 26 & 12 & 18.85 & 3.68 & 5 & 18 & 17 \\
\hline$S_{11}$ & 12.7 & 1 & 5.71 & 2.05 & 42 & 6 & 6 & 22 & 11 & 16.63 & 3.1 & 5 & 17 & 17 \\
\hline$S_{12}$ & 11 & 1.4 & 5.79 & 1.78 & 42 & 6 & 5 & 15.5 & 1 & 11.06 & 2.84 & 5 & 11.75 & 13 \\
\hline$S_{13}$ & 58.4 & 20.5 & 37.86 & 8.28 & 43 & 38.75 & 41 & - & - & - & - & - & - & - \\
\hline$S_{14}$ & 26.4 & 7 & 15.62 & 4.40 & 44 & 15.4 & 17 & 26.5 & 17.5 & 22.81 & 2.99 & 4 & 24 & 25 \\
\hline$S_{15}$ & 17 & 3.3 & 9.25 & 2.65 & 44 & 9 & 8 & 17.5 & 12 & 14.34 & 1.94 & 4 & 13.75 & 13 \\
\hline$S_{16}$ & 11 & 2 & 4.47 & 1.24 & 44 & 4.1 & 4 & 6 & 3.5 & 4.79 & 0.72 & 3 & 6 & 5 \\
\hline$S_{17}$ & 12 & 1 & 4.51 & 1.45 & 44 & 4.4 & 5 & - & - & - & - & - & - & - \\
\hline$S_{18}$ & 25 & 6.4 & 16.52 & 3.71 & 44 & 16.9 & 19 & 19 & 7 & 11.65 & 2.85 & 5 & 11 & 8 \\
\hline S19 & 13 & 1 & 4.91 & 1.87 & 44 & 4.4 & 4 & 11 & 3 & 6.96 & 2.12 & 5 & 6.75 & 6 \\
\hline$S_{20}$ & 122 & 40 & 86.66 & 20.68 & 38 & 24.9 & 78 & - & - & - & - & - & - & - \\
\hline S21 & 113.5 & 29.4 & 71.10 & 18.58 & 38 & 78.95 & 78 & - & - & - & - & - & - & - \\
\hline$S_{22}$ & 90.5 & 28 & 63.59 & 15.68 & 43 & 63 & 50 & - & - & - & - & - & - & - \\
\hline$S_{23}$ & 57 & 18 & 36.97 & 8.97 & 40 & 35.8 & 43 & - & - & - & - & - & - & - \\
\hline $\mathrm{S}_{24}$ & 12.6 & 1 & 5.61 & 1.99 & 40 & 5.2 & 6 & - & - & - & - & - & - & - \\
\hline$S_{25}$ & 29 & 4 & 13.31 & 1.62 & 38 & 13 & 12 & 20 & 13 & 6.39 & 1.28 & 5 & 16 & 16 \\
\hline S26 & 19 & 1 & 10.18 & 3.36 & 34 & 10 & 12 & & & & & & & \\
\hline$S_{27}$ & 10 & 6 & 7.91 & 0.75 & 34 & 8 & 8 & 8 & 8 & 8 & 0 & 5 & 8 & 8 \\
\hline $\mathrm{S}_{28} 8$ & 8 & 5 & 7.76 & 0.71 & 33 & 8 & 8 & - & - & - & - & - & - & - \\
\hline $\mathrm{S}_{29^{\dagger}}$ & 8 & 5 & 7.67 & 0.85 & 33 & 8 & 8 & - & - & - & - & - & - & - \\
\hline $\mathrm{S}_{30} \mathrm{O}$ & 8 & 5 & 7.72 & 0.77 & 32 & 8 & 8 & - & - & - & - & - & - & - \\
\hline$S_{31}{ }^{\dagger}$ & 8 & 8 & 8 & o & 32 & 8 & 8 & - & - & - & - & - & - & - \\
\hline$S_{32}$ & 11 & 4 & 7.14 & 1.29 & 41 & 7 & 8 & - & - & - & - & - & - & - \\
\hline$S_{33}$ & 4 & 0 & 0.22 & 0.37 & 41 & o & o & - & - & - & - & - & - & - \\
\hline$S_{34}$ & 52 & o & 17.22 & 7.48 & 41 & 16 & 16 & - & - & - & - & - & - & - \\
\hline$S_{35}$ & 33 & 6 & 18.15 & 4.17 & 39 & 18 & 19 & - & - & - & - & - & - & - \\
\hline$S_{36}$ & 111 & 40 & 81.34 & 14.91 & 38 & 81.5 & 84 & - & - & - & - & - & - & - \\
\hline$S_{3}: S_{1}$ & 0.37 & 0.28 & 0.32 & 0.03 & 4 & 0.32 & - & - & - & - & - & - & - & - \\
\hline$S_{7}: S 6$ & 5.32 & 1.05 & 2.78 & 0.86 & 44 & 2.71 & - & 8.00 & 2.71 & 4.65 & 1.27 & 5 & 4.63 & 3 \\
\hline$S_{13}: S_{1}$ & 0.41 & 0.24 & 0.32 & 0.04 & 37 & 0.32 & - & 0.44 & 0.24 & 0.33 & 0.09 & 5.00 & 0.28 & - \\
\hline$S_{15}: S_{14}$ & 0.99 & 0.3 & 0.61 & 0.16 & 44 & 0.60 & - & 0.72 & 0.50 & 0.63 & 0.069 & 4 & 0.65 & 0.54 \\
\hline S11: oral arm length & 0.243 & 0.1 & 0.17 & 0.04 & 42 & 0.17 & - & 0.44 & 0.24 & 0.34 & 0.053 & 5 & 0.65 & 0.31 \\
\hline
\end{tabular}


arms, each divided into a naked proximal (ratio to bell diameter: 0.08; Table 4) and a three-winged distal (ratio to bell diameter: 0.21 ; Table 4) portion, latter almost three times longer than former (mean: 2.78, SD: 0.86; Table 3); distal portion with one adoral and two aboral rows of mouthlets and club-shaped appendages, adoral row originating proximal to and terminating distad of the two aboral rows; terminating in a naked pyramidal club, proportion of terminal club length to oral arm length low (mean: 0.17, SD: 0.04; Table 3). In life, exumbrella transparentwhite; oral arms transparent-white, bearing light-brown mouthlets and appendages; terminal clubs transparent-white; gonads cream. In preservation, they are all transparent-cream.

The canal system with a continuous ring canal, and four perradial and four inter-radial canals extending to umbrella margin and eight adradial canals terminating at the ring canal. Intra-circular network of anastomosing canals originating from ring canal $(\sim 7$ connections with the ring canal; Table 3), no communication with the gastric cavity except occasionally through the perradial and inter-radial canals (0.22 connections with adjacent radial canals; Table 3 \& Figure 3$)$, less dense $(\sim 17$ connection points within intracircular network; Table 3) than that of the extra-circular network, which does not extend into lappets.

Eight rhopalia (range: 6-10; Table 3), situated in pits with radiating furrows, flanked laterally by ocular lappets that are smaller than, and slightly dorsal to, velar lappets. Twelve velar lappets per octant (range 4-29; Table 3), each with a row of small conical projections (mode: 12, range: 1-19; Table 3) mid-dorsally. There are approximately 84 (range 40-111; Table 3) annular muscles on subumbrellar surface. Four crescent shaped ostia lead from the gonadal and gastrovascular cavity; ostial and inter-ostial widths approximately equal (mean: 0.61, SD: 0.16; Table 3). Gonads at the time of sampling were either immature and thin or mature and plump. Maturity in specimens was reached when external bell diameter reached $\sim 100 \mathrm{~mm}$. Of the 48 medusae examined 26 had developed gonads.

\section{VARIATION}

The majority of the meristic measurements taken were found to be size dependant (Table 3), although some were not. These features are highlighted in Table 3, as they can be useful in species-level comparisons. Adradial canals sometimes appear to extend beyond the ring canal but on closer inspection extensions are thinner, and seem to be more subdivided than those of the rhopalial canals (Figure 3).

\section{REMARKS}

A comparison of the key morphological and meristic features that can be used to distinguish the three recognized species of Crambionella, together with the appropriate data from this study are shown in Table 5. From this it can be seen that the number of velar lappets in each octant of the present material was similar to that of C. stuhlmanni (Chun, 1896). The presence of conical projections on the dorsal median line of each lappet was also consistent with observations for C. stuhlmanni, and this feature can be used to distinguish the material from $C$. orsini (Menon, 1930, 1936; Stiasny, 1937) but not from C. annandalei (Rao, 1931; Stiasny, 1937). However, the high ratio of terminal club length to the oral arm length as well as the ratio between distal winged portion and naked proximal portion of the oral arm separate C. annandalei (Menon, 1930; Rao, 1931) from the present material. Both C. annandalei and C. orsini possess
Table 4. Summary of all ratios (morphological features divided by external bell diameter) of Crambionella specimens from St Lucia Estuary and C. orsini specimens examined from the Natural History Museum (NHM), London. Highlighted (bold typeface, left-hand side column) are those logged ratios that were significantly correlated with external bell diameter $(P<0.05$, accepting Bonferonni correction) in the case of the St Lucia material. Excluded standardized measurements included in correlation analyses $S_{2}$ and $S_{3}$ as well as all proportions and meristic data except $S_{35}$ and $S_{3} 6$ (indicated by ${ }^{\dagger}$ ). Highlighted $P$-values (right-hand side column) are the standardized variables that differed significantly $(P<0.05$, accepting Bonferonni correction) between C. orsini and the specimens of Crambionella from the St Lucia Estuary, as determined using two-tailed $t$-tests.

\begin{tabular}{|c|c|c|c|c|c|c|c|}
\hline \multirow[t]{2}{*}{ Morphological feature } & \multicolumn{3}{|c|}{$\begin{array}{l}\text { Crambionella (St } \\
\text { Lucia) }\end{array}$} & \multicolumn{3}{|c|}{$\begin{array}{l}\text { Crambionella } \\
\text { orsini (NHM) }\end{array}$} & \multirow[t]{2}{*}{$P$} \\
\hline & Mean & SD & $\mathbf{N}$ & Mean & SD & $\mathbf{N}$ & \\
\hline $\mathrm{S}_{3}{ }^{\dagger}$ & 0.03 & 0.09 & 4 & - & - & - & - \\
\hline $\mathrm{S}_{4}$ & 0.10 & 0.05 & 38 & - & - & - & - \\
\hline $\mathrm{S}_{5}$ & 0.04 & 0.01 & 42 & 0.04 & 0.01 & 5 & 0.55 \\
\hline S6 & 0.08 & 0.02 & 42 & 0.06 & 0.01 & 5 & 0.31 \\
\hline $\mathrm{S}_{7}$ & 0.21 & 0.04 & 42 & 0.27 & 0.01 & 5 & 0.01 \\
\hline S8 & 0.09 & 0.03 & 42 & 0.08 & 0.01 & 5 & 0.51 \\
\hline S9 & 0.05 & 0.01 & 42 & 0.04 & 0.01 & 5 & 0.17 \\
\hline $\mathrm{S}_{10}$ & 0.13 & 0.02 & 42 & 0.13 & 0.02 & 5 & 0.52 \\
\hline$S_{11}$ & 0.05 & 0.02 & 40 & 0.11 & 0.01 & 5 & $<0.0025$ \\
\hline $\mathrm{S}_{12}$ & 0.05 & 0.01 & 40 & 0.07 & 0.01 & 5 & $<0.0025$ \\
\hline $\mathrm{S}_{13}$ & 0.28 & 0.11 & 37 & 0.33 & 0.09 & 5 & 0.33 \\
\hline $\mathrm{S}_{14}$ & 0.13 & 0.02 & 42 & 0.12 & 0.07 & 5 & 0.009 \\
\hline $\mathrm{S}_{15}$ & 0.08 & 0.02 & 42 & 0.08 & 0.05 & 5 & 0.04 \\
\hline $\mathrm{S}_{16}$ & 0.04 & 0.01 & 42 & 0.02 & 0.02 & 5 & 0.23 \\
\hline $\mathrm{S}_{17}$ & 0.04 & 0.01 & 42 & - & - & - & - \\
\hline $\mathrm{S}_{18}$ & 0.12 & 0.01 & 42 & 0.08 & 0.01 & 5 & $<0.0025$ \\
\hline $\mathrm{S}_{19}$ & 0.04 & 0.01 & 42 & 0.05 & 0.01 & 5 & 0.03 \\
\hline $\mathrm{S}_{20}$ & 0.54 & 0.19 & 38 & - & - & - & - \\
\hline $\mathrm{S}_{21}$ & 0.66 & 0.23 & 38 & - & - & - & - \\
\hline $\mathrm{S}_{22}$ & 0.49 & 0.17 & 38 & - & - & - & - \\
\hline $\mathrm{S}_{23}$ & 0.26 & 0.13 & 34 & - & - & - & - \\
\hline $\mathrm{S}_{24}$ & 0.04 & 0.03 & 34 & - & - & - & - \\
\hline $\mathrm{S}_{25}{ }^{\dagger}$ & 0.11 & 0.05 & 38 & 0.11 & 0.02 & 5 & 0.38 \\
\hline $\mathrm{S}_{2} 6^{\dagger}$ & 0.07 & 0.04 & 34 & - & - & - & - \\
\hline $\mathrm{S}_{27}{ }^{\dagger}$ & 0.06 & 0.03 & 37 & 0.06 & 0.01 & 5 & 0.27 \\
\hline $\mathrm{S}_{2} 8^{\dagger}$ & 0.06 & 0.03 & 37 & - & - & - & - \\
\hline $\mathrm{S}_{29}{ }^{\dagger}$ & 0.06 & 0.03 & 34 & - & - & - & - \\
\hline $\mathrm{S}_{30}{ }^{\dagger}$ & 0.05 & 0.03 & 36 & - & - & - & - \\
\hline $\mathrm{S}_{31}{ }^{\dagger}$ & 0.07 & 0.02 & 42 & - & - & - & - \\
\hline $\mathrm{S}_{32}{ }^{\dagger}$ & 0.06 & 0.02 & 38 & - & - & - & - \\
\hline $\mathrm{S}_{33}{ }^{\dagger}$ & 0.00 & 0.00 & 16 & - & - & - & - \\
\hline $\mathrm{S}_{34}{ }^{\dagger}$ & 0.13 & 0.07 & 38 & - & - & - & - \\
\hline$S_{35}$ & 0.13 & 0.08 & 33 & - & - & - & - \\
\hline S36 & 0.65 & 0.28 & 38 & - & - & - & - \\
\hline $\mathrm{S}_{3}: \mathrm{S}_{1}^{\dagger}$ & - & - & - & - & - & - & - \\
\hline $\mathrm{S}_{7}: \mathrm{S}^{\dagger}$ & - & - & - & - & - & - & $<0.0025$ \\
\hline $\mathrm{S}_{13}: \mathrm{S}_{1}^{\dagger}$ & - & - & - & - & - & - & 0.90 \\
\hline $\mathrm{S}_{15}: \mathrm{S}_{14}^{\dagger}$ & - & - & - & - & - & - & 0.77 \\
\hline S11: oral arm length $^{\dagger}$ & - & - & - & - & - & - & $<0.0025$ \\
\hline
\end{tabular}

accessory orbicular mouth appendages (Rao, 1931; Menon, 1936; Stiasny, 1937; Kramp, 1961), which both the present material and C. stuhlmanni lack (Stiasny, 1922; Kramp, 1961).

Although meristic differences (Table 3 ) between the present material and $C$. orsini are pronounced enough to allow ready separation, and generally agree with the literature (see Table 5) (Vanhöffen, 1888; Chun, 1896; Mayer, 1910; Stiasny, 1922, 1923, 1937; Menon, 1930, 1936; Rao, 1931; Ranson, 1945; Nair, 1946; Kramp, 1956, 1961, 1970), there are also clear differences in some of the standardized morphometric data (Table 4). 
Table 5. A character matrix highlighting morphological features that differ among the three Crambionella species. (Vanhöffen, 1888; Chun, 1896; Mayer, 1910; Stiasny, 1922, 1923, 1937; Menon, 1930, 1936; Roa, 1931; Ranson, 1945; Nair, 1946; Kramp, 1956, 1961, 1970) and the Crambionella material under investigation. Recorded geographical ranges are also given for all species.

\begin{tabular}{|c|c|c|c|c|}
\hline Feature & C. orsini & C. annandalei & C. stuhlmanni & $\begin{array}{l}\text { Crambionella stuhlmanni- } \\
\text { present study }\end{array}$ \\
\hline Umbrella diameter & $55-210 \mathrm{~mm}$ & $80-200 \mathrm{~mm}$ & $80-200 \mathrm{~mm}$ & 62-181 mm (Table 3) \\
\hline $\begin{array}{l}\text { Proportion of umbrella height to } \\
\text { umbrella diameter }\end{array}$ & 0.3 & 0.3 & $0.3-0.5$ & Mean: $0.32 \pm 0.03$ (Table 3) \\
\hline $\begin{array}{l}\text { Number of velar lappets in each } \\
\text { octant }\end{array}$ & 16 & 14 & 12 & Mode: 12 ; range: $4-29$ (Table 3 ) \\
\hline $\begin{array}{l}\text { Conical projections on velar } \\
\text { lappets }\end{array}$ & Absent & Present & Present & Present \\
\hline Number of conical projections & - & $14-16$ & $15-18$ & Mode: 12 ; range: $1-19$ (Table 3 ) \\
\hline $\begin{array}{l}\text { Proportion of oral disc to external } \\
\text { umbrella diameter }\end{array}$ & $0.5-0.6$ & $\leq 0.5$ & 0.5 & Mean: $0.32 \pm 0.04$ (Table 3 ) \\
\hline $\begin{array}{l}\text { Accessory orbicular mouth } \\
\text { appendages on distal winged } \\
\text { portion }\end{array}$ & Present & Present & Absent & Absent \\
\hline $\begin{array}{l}\text { Proportion of distal winged } \\
\text { portion to naked proximal } \\
\text { portion }\end{array}$ & $\begin{array}{l}\text { Three to four times as } \\
\text { long }\end{array}$ & $\begin{array}{l}\text { More than six times } \\
\text { as long }\end{array}$ & $\begin{array}{l}\text { Two to three times as } \\
\text { long }\end{array}$ & Mean: $2.78 \pm 0.86$ (Table 3) \\
\hline $\begin{array}{l}\text { Proportion of terminal club } \\
\text { length to oral arm length }\end{array}$ & 0.125 & 0.5 & 0.33 & Mean: $0.17 \pm 0.04$ (Table 3) \\
\hline $\begin{array}{l}\text { Proportion of ostia to inter-ostia } \\
\text { width }\end{array}$ & $\begin{array}{l}1 / 3-1 / 2 \text { as wide as } \\
\text { inter-ostial } \\
\text { columns }\end{array}$ & $\begin{array}{l}1 / 2 \text { as wide as } \\
\text { inter-ostial } \\
\text { columns }\end{array}$ & $\begin{array}{l}1 / 4-1 / 3 \text { as wide as } \\
\text { inter-ostial } \\
\text { columns }\end{array}$ & Mean: $0.61 \pm 0.16$ (Table 3) \\
\hline Inter-rhopalial canals termination & Ring canal & Ring canal & Ring canal & Ring canal \\
\hline $\begin{array}{l}\text { Number of intra-circular } \\
\text { anastomosing canals } \\
\text { connected to ring canal }\end{array}$ & Rare & Rare & Rare & Rare (Table 3) \\
\hline $\begin{array}{l}\text { Intra-circular anastomosing canal } \\
\text { connections to inter-rhopalial } \\
\text { or rhopalial canal }\end{array}$ & Inter-rhopalial canals & - & Rhopalial canals & $\begin{array}{l}\text { Connections to both inter- and } \\
\text { rhopalial canals (Figure 3) }\end{array}$ \\
\hline Geographical range & $\begin{array}{l}\text { South-west and } \\
\text { south-east coast of } \\
\text { India, Krusadai } \\
\text { Islands, Persian } \\
\text { Gulf to Red Sea and } \\
\text { Kenya to Seychelles } \\
\text { Islands }\end{array}$ & $\begin{array}{l}\text { Bay of Bengal and } \\
\text { Andaman Islands }\end{array}$ & $\begin{array}{l}\text { Along the coasts of } \\
\text { Mozambique and } \\
\text { Madagascar }\end{array}$ & St Lucia Estuary, South Africa \\
\hline
\end{tabular}

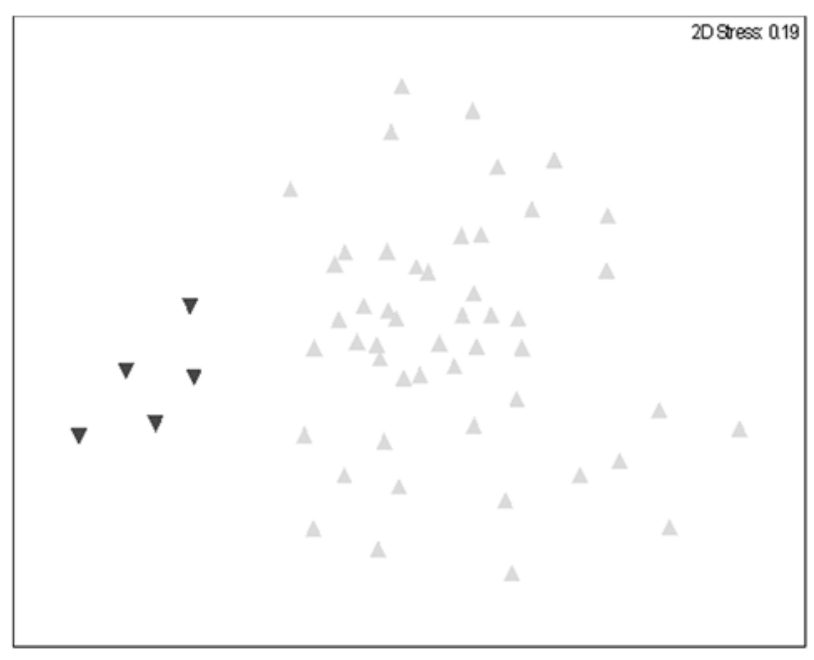

Fig. 4. Non-metric multi-dimensional scaling (NMDS) of standardized morphometric data illustrating the morphological dissimilarity between Crambionella medusa collected in the St Lucia Estuary (grey) and C. orsini (black) examined at the Natural History Museum, London. Stress value is indicated.
The results of the NMDS analysis (Figure 4) show that the two species are well separated, and even though the stress value is relatively high, the CAP was able to successfully categorize all specimens into the correct group (the permutation test results were significant: $P<0.001$ ). For the canonical procedure a subset of three PCO axes were used based on the 'leave-one-out' diagnostics, which accounted for $66.74 \%$ of the total variation in the species data. The first squared canonical correlation $\left(\delta_{1}^{2}\right)$ was high: 0.56. Similar results were also obtained from the ANOSIM, where the Global $R$ value of 0.67 was highly significant $(P<0.001)$. The variables contributing to the dissimilarities between species are highlighted in Table 6, foremost of which are the various characteristics of the oral arm.

For cytochrome $c$ oxidase subunit I (COI) a maximum length of 660 nucleotides was amplified from three Crambionella specimens sampled in the St Lucia Estuary (GenBank accession

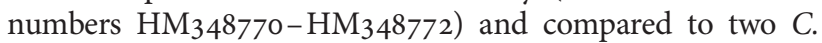
orsini specimens (sequences downloaded from GenBank, acces-

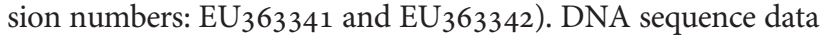
from COI showed an average of $11.84 \%$ pairwise sequence difference between the material examined in this study and $C$. orsini. Dawson \& Jacobs (2001) suggest that differences of 
Table 6. Standardized morphometric data that contributed most to the dissimilarity between Crambionella material collected from the St Lucia Estuary and C. orsini specimens examined at the Natural History Museum, London, as determined by SIMPER analysis.

\begin{tabular}{|c|c|c|}
\hline Morphological feature & Contribution \% & Cumulative \% \\
\hline Length of the terminal club & 24.10 & 24.10 \\
\hline $\begin{array}{l}\text { Terminal club length: total oral } \\
\text { arm length }\end{array}$ & 17.89 & 41.99 \\
\hline $\begin{array}{l}\text { Length of the distal portion of the } \\
\text { oral arm: length of proximal } \\
\text { portion of the oral arm }\end{array}$ & 12.77 & 54.76 \\
\hline Width of terminal club & 6.78 & 61.54 \\
\hline Length of oral pillar & 5.81 & 67.35 \\
\hline $\begin{array}{l}\text { Length of distal portion of } \\
\text { oral arm }\end{array}$ & 4.13 & 71.48 \\
\hline $\begin{array}{l}\text { Length of proximal portion of } \\
\text { oral arm }\end{array}$ & 4.11 & 75.60 \\
\hline Width of ostia & 3.20 & 78.80 \\
\hline Oral disc diameter & 2.81 & 81.61 \\
\hline Length of ostia & 2.76 & 84.37 \\
\hline Width of oral pillar & 2.53 & 86.91 \\
\hline Ostia width: inter-ostia width & 2.49 & 89.40 \\
\hline Depth of naked portion of oral arm & 2.01 & 91.41 \\
\hline
\end{tabular}

10-20\% between COI sequences set the standard for species level divergence. Phylogenetic analyses computed using COI sequence data demonstrate a monophyletic Crambionella clade (Figure 5). The consensus tree was supported by generally high bootstrap values, except at the branch that illustrated Catostylidae to be paraphyletic to the other rhizostome families represented. This is in contrast to previous molecular phylogenetic analyses executed on rhizostomes using COI (Daryanabard \& Dawson, 2008) and future work is needed to verify the findings in the present study. For internal transcribed spacer one (ITS1) a maximum length of 335 nucleotides was amplified from two Crambionella specimens sampled in the St Lucia Estuary (GenBank accession numbers HM348773 and

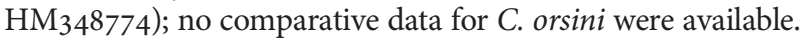

Although on balance the material most closely resembles $C$. stuhlmanni, which is in agreement with its geographical distribution (Table 5), there was one feature at odds with previous descriptions. In the present specimens the intra-circular anastomosing canal network sometimes connected to both the rhopalial and inter-rhopalial canals (Figure 3), whilst in the original descriptions the anastomosing canals were only connected to rhopalial canals (Stiasny, 1922). It is unlikely that these discrepancies reflect erroneous observations on the part of Stiasny; but rather it is probable that previous descriptions overlooked this rare feature due to small sample sizes examined. Scyphozoans often display considerable intra-specific morphological variation between geographically isolated or separated populations (Brewer, 1991; Bolton \& Graham, 2004; Dawson, 2005a). Morphological variation is often as a result of phenotypic plasticity, a response to variable environmental conditions (Dawson et al., 2001; Bolton \& Graham, 2004). Dawson (2005b) highlights the importance of thorough geographical sampling, in combination with adequate sample sizes (as

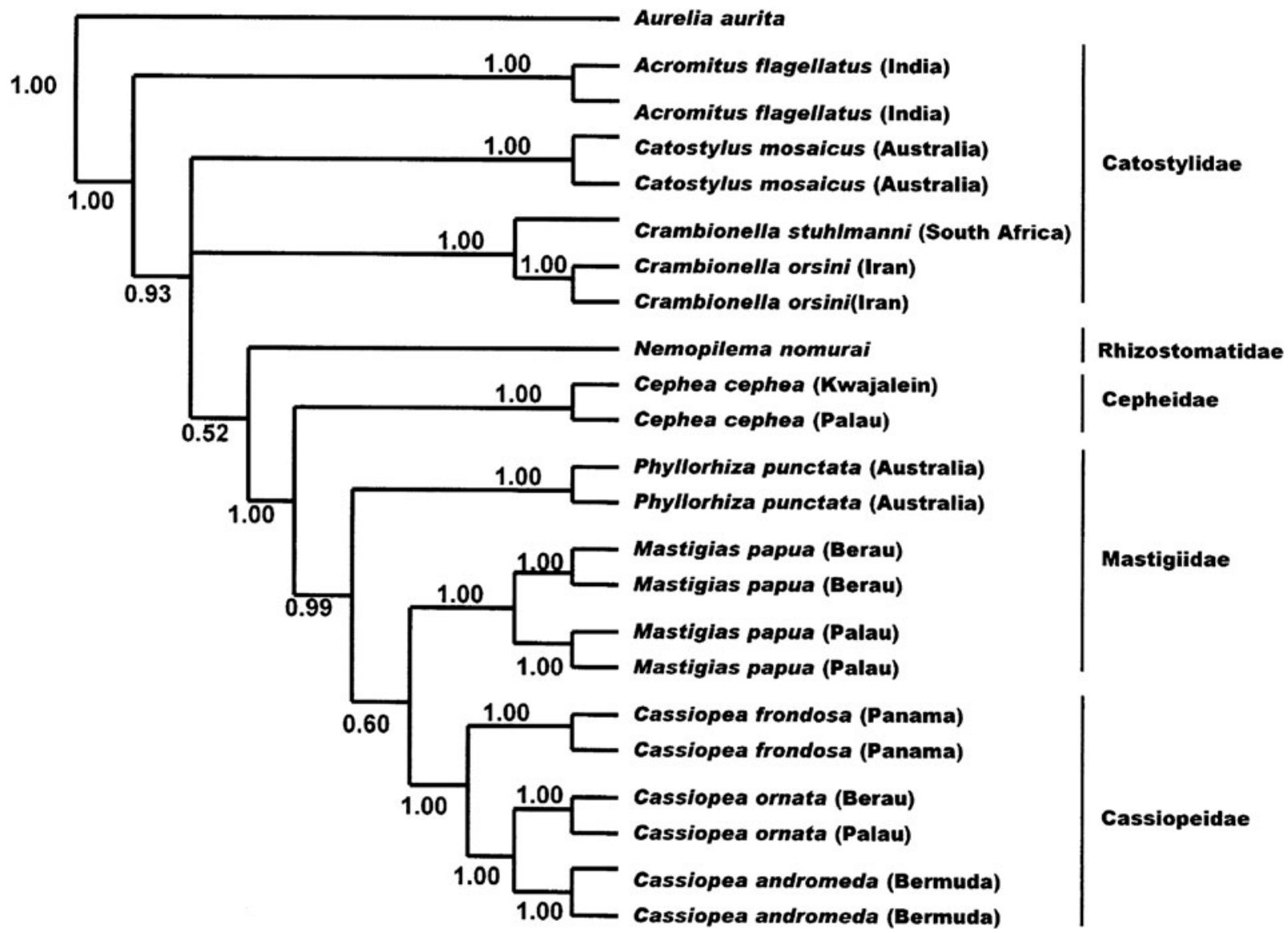

Fig. 5. A consensus tree of Rhizostomeae (original sequence data received from Professor M.N. Dawson), and outgroup, based on 474 nucleotides from cytochrome $c$ oxidase subunit I (COI). Analysed by direct optimization in POY. Bootstrap values are indicated. 
observed in this study), to get a more accurate representation of morphological variation.

Molecular analyses are increasingly being used in scyphozoan systematics (Dawson \& Jacobs, 2001; Schroth et al., 2002; Dawson, 2003, 2004, 2005a, b, c, d, e; Holland et al., 2004) and the decision about whether to use molecular or morphological analyses when describing species is subject to much debate (Dawson, 2005f). Molecular data increase the number of objective characters used, which enhances the likelihood of distinguishing taxa and permits phylogenetic reconstruction, free of impractical or inappropriate morphological features (Dawson, 2004). However, in some studies molecular analyses have failed to differentiate groups that showed significant morphological, behavioural and physiological differences (Dawson, 2005a). An approach which combines all data available is therefore required in scyphozoan systematics (Dawson, 2003, 2005f). Although this study did not utilize ecological or behavioural data, integrating molecular and morphological data is an important stepping stone for future work on this species.

\section{ACKNDWLEDGEMENTS}

We are grateful to Mr Martin Hendricks (UWC) for technical support and to staff at the Natural History Museum (London) for allowing us access to Crambionella orsini. We would like to thank Marine and Coastal Management and Ezemvelo KwaZulu Natal Wildlife for giving us permission to collect material from the St Lucia Estuary and to Mr A. Bali (Marine and Coastal Management, Cape Town) and Professor R. Perissinotto (University of KwaZulu Natal, Durban) for supplying the specimens. We are also grateful to Ms Annegret Bitzer and Professor Ralf Henkel (University of the Western Cape) for their translation of German papers. We acknowledge Professor Michael N. Dawson (University of Merced, USA) for supplying us with rhizostome sequence data. Particular thanks are also due to Professors André C. Morandini (University of São Paulo, Brazil) and Michael N. Dawson for their very useful comments on a previous draft of the manuscript, and to the anonymous referees who helped us to improve the text. This work was supported by the National Research Foundation (NRF grant number 61257); the NRF-Royal Society (London) SET Development grant in Zoology to the University of the Western Cape; and the Canon Collins Trust (S.N., grant number Nee 1500).

\section{REFERENCES}

Anderson M.J., Gorley R.N. and Clarke K.R. (2008) PERMANOVA+ for PRIMER: guide to software and statistical methods. Plymouth Marine Laboratory: PRIMER-E Ltd.

Anonymous (2008) iSimangaliso Wetland Park Kwazulu-Natal, South Africa. United Nations Environment Programme and World Conservation Monitoring Centre [available at: http://www.unepwcmc.org/sites/wh/pdf/iSimangaliso.pdf].

Billett D.S.M., Bett B.J., Jacobs C.L., Rouse I.P. and Wigham B.D. (2006) Mass deposition of jellyfish in the deep Arabian Sea. Limnology and Oceanography 51, 2077-2083.

Bolton T.F. and Graham W.M. (2004) Morphological variation among populations of an invasive jellyfish. Marine Ecology Progress Series $278,125-139$
Brewer R.H. (1991) Morphological difference between, and reproductive isolation of, two populations of the jellyfish Cyanea in Long Island South, USA. Hydrobiologia 216/217, 471-477.

Chun C. (1896) Beitrage zur Kenntniss ostafrikanischer Medusen und Siphonophoren nach den Sammlungen Dr. Stuhlmann's. Zum Jahrbuch der Hamburgischen Wissenschaftlichen Anstalten, Jahrgang 13, $1-19$.

Clarke K.R. (1993) Non-parametric multivariate analyses of changes in community structure. Australian Journal of Ecology 18, 117-143.

Clarke K.R. and Gorley R.N. (2006) PRIMER v6: user manual/tutorial. Plymouth Marine Laboratory: PRIMER-E Ltd.

Clarke K.R. and Warwick R.M. (2001) Change in marine communities: an approach to statistical analysis and interpretation, 2nd edition. Plymouth Marine Laboratory: PRIMER-E Ltd.

Collins A.G. (2002) Phylogeny of Medusozoa and the evolution of cnidarian life cycles. Journal of Evolutionary Biology 15, 418-432.

Collins A.G., Schuchert P., Marques A.C., Jankowski T., Medina M. and Schierwater B. (2006) Medusozoan phylogeny and character evolution clarified by new large and small subunit rDNA data and an assessment of the utility of phylogenetic mixture models. Systematic Biology 55, 97-115.

Cyrus D.P., Vivier L. and Jerling H.L. (2010) Effect of hypersaline and low lake conditions on ecological functioning of St Lucia estuarine system, South Africa: an overview 2002-2008. Estuarine, Coastal and Shelf Science 86, 535-542.

Daryanabard R. and Dawson M.N. (2008) Jellyfish blooms: Crambionella orsini (Scyphozoa: Rhizostomeae) in the Gulf of Oman, Iran, 20022003. Journal of the Marine Biological Association of the United Kingdom 88, 477-483.

Dawson M.N. (2003) Macro-morphological variation among cryptic species of the moon jellyfish, Aurelia (Cnidaria: Scyphozoa) and some implications for the systematics of medusae. Marine Biology $143,369-379$

Dawson M.N. (2004) Some implications of molecular phylogenetics for understanding biodiversity in jellyfishes, with emphasis on Scyphozoa. Hydrobiologia 531, 249-260.

Dawson M.N. (2005a) Morphological variation and systematics in the Scyphozoa: Mastigias (Rhizostomeae, Mastigiidae) - a golden unstandard? Hydrobiologia 537, 185-206.

Dawson M.N. (2005b) Cyanea capillata is not a cosmopolitan jellyfish: morphological and molecular evidence for C. annaskala and $C$. rosea (Scyphozoa: Semaeostomeae: Cyaneidae) in south-eastern Australia. Invertebrate Systematics 19, 361-370.

Dawson M.N. (2005c) Morphologic and molecular redescription of Catostylus mosaicus conservativus (Scyphozoa: Rhizostomeae: Catostylidae) from south-east Australia. Journal of the Marine Biological Association of the United Kingdom 85, 723-731.

Dawson M.N. (2005d) Incipient speciation of Catostylus mosaicus (Scyphozoa, Rhizostomeae, Catostylidae), comparative phylogeography and biogeography in south-east Australia. Journal of Biogeography 32, 515-533.

Dawson M.N. (2005e) Five new subspecies of Mastigias (Scyphozoa: Rhizostomeae: Mastigiidae) from marine lakes, Palau, Micronesia. Journal of the Marine Biological Association of the United Kingdom $85,679-694$.

Dawson M.N. (2005f) Renaissance taxonomy: integrative evolutionary analyses in the classification of Scyphozoa. Journal of the Marine Biological Association of the United Kingdom 85, 733-739. 
Dawson M.N. and Jacobs D.K. (2001) Molecular evidence for cryptic species of Aurelia aurita (Cnidaria, Scyphozoa). Biological Bulletin. Marine Biological Laboratory, Woods Hole 200, 92-96.

Dawson M.N., Martin L.E. and Penland L.K. (2001) Jellyfish swarm tourists and the Christ-child. Hydrobiologia 451, 131-144.

Emanuel B.P., Bustamante R.H., Branch G.M., Eekhout S. and Odendaal F.J. (1992) A zoogeographic and functional approach to the selection of marine reserves on the west coast of South Africa South African Journal of Marine Science 12, 341-354.

Fielding P.J., Forbes A.T. and Demetriades N.T. (1991) Chlorophyll concentrations and suspended particulate loads in St Lucia, a turbid estuary on the east coast of South Africa. African Journal of Marine Science 11, 491-498.

Folmer O., Black M., Hoeh W., Lutz R. and Vrijenhoek R. (1994) DNA primers for amplification of mitochondrial cytochrome $c$ oxidase subunit I from diverse metazoan invertebrates. Molecular Biology and Biotechnology 3, 294-299.

Gibbons M.J., Abiahy B.B., Angel M., Assuncao C.M.L., Bartsch I., Best P., Biseswar R., Bouillon J., Bradford-Grieve J.M., Branch W., Burreson E., Cannon L., Casanova J-P., Channing A., Child C.A., Compagno L., Cornelius P.F.S., Dadon J.R., David J.H.M., Day J., Della Croce N., Emschermann P., Erseus C., Esnal G., Gibson R., Griffiths C.L., Hayward P.J., Heard R., Heemstra P., Herbert D., Hessler R., Higgins R., Hiller N., Hirano Y.M., Kensley B., Kilburn R., Kornicker L., Lambshead J., Manning R., Marshall D., Mianzan H., Monniot C., Monniot F., Newman W., Nielsen C., Patterson G., Pugh P., Roeleveld M., Ross A., Ryan P., Ryland J.S., Samaai T., Schleyer M., Schockaert E., Seapy R., Shiel R., Sluys R., Southward E.C., Sulaiman A., Thandar A., van der Land J., van der Spoel S., van Soest R., Vetter E., Vinogradov G., Williams G. and Wooldridge T. (1999) The taxonomic richness of South Africa's marine fauna: a crisis at hand. South African Journal of Science 95, 8-12.

Gibbons M.J., Buecher E., Thibault-Botha D. and Helm R.R. (2010a) Patterns in marine hydrozoan richness and biogeography around southern Africa: implications of life-history strategy. Journal of Biogeography 37, 606-616.

Gibbons M.J., Janson L.A., Ismail A. and Samaai T. (2010b) Life-cycle strategy, species richness and distribution in marine Hydrozoa (Cnidaria: Medusozoa). Journal of Biogeography 37, 441-448.

Hamner W.H. and Dawson M.N. (2009) A review and synthesis on the systematics and evolution of jellyfish blooms: advantageous aggregations and adaptive assemblages. Hydrobiologia 616, 161-191.

Holland B.S., Dawson M.N., Crow G.L. and Hofmann D.K. (2004) Global phylogeography of Cassiopea (Scyphozoa: Rhizostomeae): molecular evidence for cryptic species and multiple invasion of the Hawaiian Islands. Marine Biology 145, 1119-1128.

Jerling H.L., Vivier L. and Cyrus D.P. (2010) Response of the mesozooplankton community of the St Lucia estuary, South Africa, to a mouth-opening event during an extended drought. Estuarine, Coastal and Shelf Science 86, 543-552.

Kramp P.L. (1956) Medusae of the Iranian Gulf. Videnskabelige Meddelelser fra Dansk Naturhistorik Forening 118, 235-242.

Kramp P.L. (1961) Synopsis of the medusae of the world. Journal of the Marine Biological Association of the United Kingdom 40, 1-469.

Kramp P.L. (1970) Zoogeographical studies on Rhizostomeae (Scyphozoa). Videnskabelige Meddelelser fra Dansk Naturhistorisk Forening 133, 7-30.

Marques A.C. and Collins A.G. (2004) Cladistic analysis of Medusozoa and cnidarian evolution. Invertebrate Biology 123, 23-42.

Mayer A.G. (1910) Volume III: Schyphomedusae. In Medusae of the world. Washington: Carnegie Institute, pp. 499-735.
McManus G.B. and Katz L.A. (2009) Molecular and morphological methods for identifying plankton: what makes a successful marriage? Journal of Plankton Research 31, 1119-1129.

Menon M.G.K. (1930) The Schyphomedusae of Madras and the neighbouring coast. Bulletin of the Madras Government, New Series, Natural History Section 3, 1-28.

Menon M.G.K. (1936) Schyphomedusae of the Krusadai Island. Bulletin of the Madras Government, New Series, Natural History Section 1, $1-9$.

Mianzan H.W. and Cornelius P.F.S. (1999) Cubomedusae and Scyphomedusae. In Boltovskoy D. (ed.) South Atlantic zooplankton (volume 1). Leiden: Backhuys Publishers, pp. 513-559.

Nair K.K. (1946) Medusae of Travancore and their correlation with inshore fishing. Proceedings of the First Indian Science Congress 32, 97.

Pillay D. and Perissinotto R. (2008) The benthic macrofauna of the St Lucia Estuary during the 2005 drought year. Estuarine, Coastal and Shelf Science 77, 35-46.

Quinn G. and Keough M. (2002) Hypothesis testing. In Experimental design and data analysis for biologists. Cambridge: Cambridge University Press, pp. $32-54$.

Ranson G. (1945) Les Scyphomeduses de la collection du Muséum National d'Histoire Naturelle Paris. II. Catalogue raisonne; origine des recoltes. Bulletin du Muséum National d'Histoire Naturelle Paris Series 2, 16, 312-320.

Rao H.S. (1931) Notes on Scyphomedusae in the Indian museum. Records of the Indian Museum 33, 25-62.

Schroth W., Jarms G., Streit B. and Schierwater B. (2002) Speciation and phylogeography in the cosmopolitan marine moon jelly, Aurelia sp. BioMed Central Evolutionary Biology 2, 1-10.

Stiasny G. (1921) Studien über Rhizostomeen. Capita Zoologica 1, 129130.

Stiasny G. (1922) Ergebnisse der Nachuntersuchung einiger Rhizostomeer-Typen Haeckel's und Chun's aus dem zoologischen Museum in Hamburg. Zooogische Mededelingen 7, 41-60.

Stiasny G. (1923) Ergebnisse der Nachuntersuchung einiger Rhizostomeer-Typen Ehrenberg's, Haeckel's und Vanhoffen's aus den zoologischen Museen im Berlin und Konigsberg. Zooogische Mededelingen 7, 225-242.

Stiasny G. (1937) Scyphomedusae. John Murray Expedition 1933-1934, Scientific Reports 4, 203-242.

UNESCO (2008) Report on the 32nd Session of the WH Committee. Paris: UNESCO.

Vanhöffen E. (1888) Untersuchungen über semaeostome und rhizostome Medusen. Bibliotheca Zoologica 3, 1-52.

Varón A., Vinh L.S., Bomash I. and Wheeler W.C. (2009) POY 4.1.1. American Museum of Natural History [available on internet at http://research.amnh.org/scicomp/projects/poy.php].

and

Zar J.H. (1999) Biostatistical analysis. 4th edition. India: Dorling Kindersley.

\section{Correspondence should be addressed to:}

M.J. Gibbons

Department of Biodiversity and Conservation Biology

University of the Western Cape

Private Bag $\mathrm{X}_{17}$

Bellville 7535

South Africa

email: mgibbons@uwc.ac.za 